Revista de

Contabilidade e Organizações

www.rco.usp.br
DOI: http://dx.doi.org/10.11606/issn.1982-6486.rco.2021.166382

Journal of

Accounting and

Organizations

\title{
Accountability and social control: how the process works
}

\author{
Prestação de contas e controle social: como o processo funciona
}

Andrea de Oliveira Gonçalves ${ }^{\mathrm{a}}$, João Abreu de Faria Bilhim ${ }^{\mathrm{b}}$, Ricardo Borges de Rezende ${ }^{\mathrm{a}}$, Rodrigo de Souza Gonçalves $^{\mathrm{a}}$

${ }^{a}$ Universidade de Brasilia

"Universidade de Lisboa

Keywords

Accountability process.

Social control.

Participatory management.

\begin{abstract}
Adopting an action research approach, this study presents the findings of an analysis of accountability and social control processes in place between the local government (Municipal Health Office) and the Anápolis-Brazil Municipal Health Council. The different stages of the action research process entailed: observation of plenary meetings, analysis of the composition of the council, a group interview with council members and the training of council members. The main results were the tabling and approval of a resolution defining a template for accountability reports and the drafting of a handbook with guidelines on how to read and analyze accountability reports. Members of the health council were seen to change their views concerning the process of analyzing the reports, the new emphasis being on their quality and on connecting them with the planning information. In the light of Habermas's perspective, the authors question the role of training and the intention implicit in the guidelines: are they an opportunity for empowerment/liberation or, on the contrary, an instrument of domination and alienation?
\end{abstract}

\section{Resumo}

Este estudo apresenta resultados de análise do processo de prestação de contas e controle social entre a Secretaria Municipal de Saúde e o Conselho Municipal de Saúde de Anápolis-Brasil. No processo de pesquisa-ação, foram realizados diferentes estágios, como observação em reuniões plenárias, composição do conselho, entrevista em grupo com membros do conselho e treinamento com membros do conselho (Thiollent, 1997). Os principais resultados são a elaboração e a aprovação de resolução que define um modelo para relatórios de prestação de contas e a elaboração de manual com diretrizes para a leitura e a análise de relatórios de prestação de contas. Os membros do conselho de saúde mudaram a forma do processo de análise dos relatórios, com ênfase na qualidade e na relação destas informações com o que foi planejado. À luz da perspectiva teórica de Habermas, os autores questionam o papel do treinamento e da padronização nesse processo. Questiona-se se este momento constitui uma oportunidade de empoderamento/libertação, ou o contrário, se os membros são um instrumento de dominação e alienação.

\section{Practical implications}

According to functionalism, accountability results in greater transparency and leads to a better understanding of the technical-financial reports and the decisionmaking process. A better understanding of technical-financial information and the decision-making process through social participation enhances the commitment of citizens, reduces conflict and results in a better public health service. From a radical perspective, however, accountability can act as an instrument of social control that alienates citizens.

\section{Copyright $(2021$ FEA-RP/USP. All rights reserved}

Corresponding author: Tel. $+55(61)$ 3107-0812

E-mail: andreagon@unb.br (A. de O. Gonçalves); jbilhim@iscsp.ulisboa.pt (J. de A. F. Bilhim); rezenderb78@gmail.com (R. B. de Rezende);

rgoncalves@unb.br(R.de S. Gonçalves)

Universidade de Brasília. Asa Norte - Brasília/DF - 70910900, Brazil 


\section{INTRODUCTION}

Functionalism argues that people are constrained by the social world they inhabit. Traditional management accounting assumes that profit maximization increases the welfare of society and its members, and that the task of the accounting control system is to program and monitor behavior to achieve such ends. According to Fayol, who set out the rationale for budgetary control, standard costing, for example, is inextricably linked to scientific management and management principles Neo-classical economics provides a basis for marginal costing and financial management and stresses notions of control based on the assumptions of economic man and on organizations that have unitary goals and are headed by a single decision-maker. The design of accounting control systems is central to Chandler's thesis on the strategy and structure of industrial enterprises (Hopper \& Powell,1985).

This paper does not adopt a functional paradigm, but pursues an alternative approach to accounting research by arguing that a radical paradigm is important for articulating new concerns and new interpretations of reality. Accounting research is currently characterized as using a wide range of diverse and often conflicting methodologies. Research that incorporates radical approaches, however, has enabled some of the accounting assumptions to be questioned. "Esta argumentação é consonante com o reconhecimento de que não há uma única verdade dentro da ciência contábil, e outras perspectivas podem enriquecer e aproximar o entendimento daquilo que já é conhecido" [This argument is in line with the recognition that there is no one truth in accounting science. Other perspectives can enrich and lead to a better understanding of what is already known] (Lourenço; Sauerbronn, 2015: 118)

This paper did not adopt a functionalist paradigm. It seeks an alternative approach to research in accounting, when it argues that a radical paradigm is important for articulating new concerns and new interpretations of reality. The use of a variety of theories is known as 'triangulation' and is a way of undertaking an analysis that is more holistic (Teixeira et al. 2012). As Cooper (1983) suggests, just how accounting systems might better serve society and organizations is rarely addressed, except in line with the criteria of managerial efficiency. The contradictions between accounting as objective fact and its socially created sources is the main issue addressed here. Some studies view accounting as a tool for mystifying social relationships and reinforcing unequal power distribution (Ryan et al. 2002). Habermas viewed the public sphere as an arena for public debate. Social control in Brazil in this particular context, especially in health councils, has a history of struggle and of commitment to society on the part of its representatives. There are, however, shortcomings in the way health councils function as bodies that are responsible for decision-making and social control. These range from how their participation is conceived (Grisotti, Patrício, \& Silva, 2010), to the way they should act when assessing accountability reports (Dias \& Vasconcelos, 2015).

With specific regard to accountability reporting by the manager of the Sistema Único de Saúde (SUS Brazilian Public Health System), which is an issue that has been considered in conference records and legislation, the way accounting information is disclosed still needs to be improved to enable members of health councils to understand it, above all because of its complexity. This complexity can be found in the submission of reports that are full of financial and budgetary details, and in other issues relating to the technical nature of the terms used, but the users of this information, health council members, are provided with no aids to help them read and analyze it (Bicalho, 2008). Roberts and Scapens (1983) describe accounting as a language of capitalism. This may, therefore, be one of the obstacles to the accountability process between government and health councils in Brazil.

How does the process of accountability and social control between local government (the health department) and the health council take place? What accountability process exists between the health department and the health council, and what social control is there between them? Is the council an ideological instrument for eliminating social tensions? Does it create a form of alienation between the department and the council? Does it aim to prevent citizens from claiming power? Is the participation of health council members merely apparent? On the contrary, leaders are provided with instruments that empower them, that enable them to understand and correctly interpret the codified language of technical reports. Do council members have co-management power? The research behind this article seeks to assess progress in the process of social control and to what extent health council members understand accountability procedures. This issue is discussed by analyzing the accountability and social control processes that exist between local government and the Municipal Health Council (Anápolis-Brazil) ${ }^{1}$. Using an action research approach to discuss accountability and social control, the study highlights how important it is for municipal health council members to reflect on their legal responsibilities, and on the social control of the local SUS management. Research by Stralen et al. (2006), Grisotti, Patrício and Silva (2010) and Saliba et al. (2009) explored the relevance of social control in the local SUS, but did not carry out the analysis undertaken by this article, which accordingly indicates the importance of carrying out further research into this issue.

\footnotetext{
${ }^{1}$ https://leismunicipais.com.br/a/go/a/anapolis/lei-ordinaria/1993/209/2098/lei-ordinaria-n-2098-1993-institui-o-conselho-municipal-desaude-e-da-outras-providencias
} 
To move reflection and debate forward vis-à-vis previous studies, we present a methodological proposal for interventionist action that entails: (i) discussion and the validation of the theoretical-empirical instrument used for assessing the quality of accounting information, with the active participation of health council members; (ii) technical training in reading and analyzing accountability reports; (iii) an assessment of the findings of this action research and whether it was able to empower council members to carry out the task; and (iv) an assessment of whether establishing a reporting template helps improve dialogue between local government and the Municipal Health Council (Thiollent, 1997).

\section{SOCIAL CONTROL, ACCOUNTABILITY AND REPORTING IN HEALTH MATTERS}

For Habermas (1989 [1962]), the public sphere is a space for public debate where issues are discussed and opinions presented, which are the fundamental prerequisites for effective democratic participation. At least in principle, the public sphere requires individuals to come together on an equal footing and to participate in a forum for public debate. At a conference in Lisbon on 28 October 2013 this same author stated that there is a sort of apathy towards politicians in the Western world and a distancing from them, and a demand on the part of citizens and protest groups for direct democracy².

Social control must accordingly play a leading role in democratic participation. Albeit indirectly, the concept of social control is found in the works of the classics of political philosophy that addressed the themes of State, power and the foundations of the right to rule, based on the relationship between individual action and history and collective action (Hobbes, 2019). Durkheim's view was that: "The more weakened the groups to which [the individual] belongs, the less he depends on them, the more he consequently depends only on himself and recognizes no other rules of conduct than what are founded on his private interests" (Durkheim 1951, p. 209).

Over the years, however, this same concept has evolved and broadened the debate around its fundamentals. In the American context, some authors have taken up and reformulated this concept as a process of building society and fostering the self-civilization of societies. In the most fundamental terms, "social control" referred to the capacity of a society to regulate itself according to desired principles and values (Ross, 1901 and 1936).

In the view of Janowitz (1975) there are various types and mechanisms of social control. Each is the result of particular antecedent variables and, in turn, each form has a different impact on social behavior. This author asks which forms of social control are most effective, that is, which enable a social group to regulate itself in terms of a set of legitimate moral principles that result in a reduction in coercive control? (Janowitz,1975, p.5). The relevant argument here, therefore, is that social control, to the extent that it is effective, "motivates" social groups.

Social control must accordingly play a leading role in democratic participation. In the view of Mészáros (1987, p.32), "by creating assessment procedures; political procedures for intervention, pressure and regulating interests", social control should be seen as a way of enforcing what society wants to do. Alvarez (2004) likewise points out that as a result of the wide debate on participation by society in the period of democratization in Brazil, the term social control has taken over from the concept of social participation which, in the view of Correia (2000) says it can be seen as participation by the "organized sectors of society" in formulating public policies, and following up on their execution through to decision with regard to resource allocation to ensure the interests of society as a whole".

To exercise social control under a democratic government, the acts of public actors should be transparent (Pinho \& Sacramento, 2009), which requires institutional change and the consequent maturing of the instruments of accountability, above all in relation to health councils in Brazil (Stralen et al. 2006; Martins et al. 2008). The term "accountability" has been used in literature alongside expressions such as "social control", "participation" and the "actual democratization of the State" (O'Donnell, 1998; Medeiros, Crantschaninov \& Silva, 2013). The term, therefore, is directly associated with democracy, especially with representative democracies, and according to Miguel $(2005, \mathrm{p} .27)$ it refers in practice to the "control that the established powers exert over each other, but above all to the need for representatives to render accounts and submit themselves to the assessment of the community".

The dependency relationship between social control and accountability in the context of public health policy can be viewed, on the one hand, by society and citizens that are aware and organized in relation to their demands, and on the other, by the State, which must provide full, clear and relevant information to the whole population with a view to improving their living conditions. 
However, this perspective leads to the dilemma analyzed by Fox (2018). In their discussion, the terms are related to six keywords with different meanings and contexts. "One of the key issues is whether accountability refers to an externally imposed tool of top-down control - or to bottom-up initiatives to address impunity and the abuse of power" (p.66). For this reason, Habermas (1989 [1962]) asked whether the existing legislative framework really seeks to achieve political legitimacy by calling on citizens to take part in assessing and taking decisions, or whether, on the contrary, by keeping the texts on which discussion is based codified, it serves instead as a tool for manipulating the wishes of citizens (Lubenow, 2007). The public sphere concept requires all participants to be represented on an egalitarian basis (Habermas, 1989 [1962]). "In recognizing this, Laughlin (1983) advocates the use of the critical methods of Habermas to provide a better understanding of accounting as a language and to provoke discourse leading to enlightenment” (Hopper \& Powell, 1985: 454).

When an accountability report is submitted, therefore, the expectation is that it will be presented in a way that allows the council member (citizen) to understand the information it contains. In other words, an attempt should be made to bridge the information gap in this area by empowering citizens to understand the discussion that is taking place in the public sphere.

\section{METHODOLOGICAL DESIGN}

This study adopted a participatory action research approach to assess the quality of the information in local government accountability reports and how health council members perceive and analyze this accountability instrument (Lewin, 1946; Soares et al. 2009; McNiff, 2013). This type of research is built up in cyclical phases that can be replicated in a spiral movement. This method was conceived in four main stages based on Soares et al. (2009) and McNiff (2013), as summarized in Table 1.

Table 1. Action research phases and techniques used in Municipal Health Councils

\begin{tabular}{ll}
\hline \multicolumn{1}{c}{ Study phase } & \multicolumn{1}{c}{ Techniques used } \\
\hline Exploratory Phase: & - Interviews with council members \\
DIAGNOSIS of the current situation & - Observation of plenary council meetings \\
& - Analysis of council rules and procedures \\
\hline & - Collection and analysis of ARs \\
Planning phase: & - Interviews with council members on the Accountability \\
PROPOSAL of the information for the analytical method & Committee (CPC), concerning perception of their analysis \\
& - Meeting with CPC \\
\hline & - Training seminar with members of the health council, \\
Action Phase: & $\begin{array}{l}\text { based on the accountability reports qualitative assessment } \\
\text { tool }\end{array}$ \\
& - Drafting of the MHC Resolution template for analysis and \\
& opinions concerning accountability reports \\
\hline Assessment Phase: & - Observation of the MHC after intervention \\
OBSERVATION of the application for adjustments & - Meetings with MHC members for their perception of the \\
\end{tabular}

Source: drawn up by the authors, adapted from Soares et al. (2009).

The Anápolis-Brazil Health Council was selected for this action research because it has an Accountability Committee ,which made it possible to interact with council members who are specifically involved in analyzing accountability reports. The Municipal Health Council of Anápolis is a collegiate body comprising government and civil society; it is an integral part of the SUS [Unified Health System]. It is also a permanent, deliberative, normative, supervisory and advisory body that is co-responsible for preparing the Municipal Health Policy, the purpose of which is to exercise social control over health actions and services of any kind, and over the economic, financial and human resource aspects of the Municipal Health Department of Anápolis. The Anápolis Health Council has 24 full members, divided between 22 committees and working groups. 
A diagnosis was made in the exploratory phase of the process of how the local government (AnápolisBrazil) reports to the Municipal Health Council. A structured and systematic observation technique was used, with items taken and adapted from Gonçalves, Gonçalves and Tavares (2011) involving: a) observation of the response by council members to the presentation of the allocation of financial resources to different healthcare sectors; this involved analyzing in particular whether members are concerned with occasional actions, or whether they assessed the report as a whole; b) observation of the relationship between the local government resource manager and council members in the light of the questions raised; c) verification of whether a channel is needed for future clarification of issues concerning the accountability reports (a communication channel between local government and the Municipal Health Council ), and; d) observation of the prior access to reports by all council members and whether they analyzed them.

These observations occurred during a meeting to present the Annual Management Report to the Board's Accountability Committee. This took place on October 12, 2012, and was attended by the author. This enabled a diagnosis to be made of the board's control environment and the involvement of its members in the accountability process.

The following documents were gathered between June and October 2012 and formed the basis of our initial analysis of the Council (Item "a") and of the documents supporting our analysis of the accountability reports (Item "b"): Item a) Council Rules of Procedure and the composition of the council and its committees; and Item b) Municipal Health Plan 2010-2013; accountability reports for years 2010 to 2012 and Municipal Health Council Opinions. The reports for 2010 to 2012 were analyzed using the research tool developed by de Oliveira Gonçalves et al. (2010).

After preliminary diagnosis, Soares et al. (2009) and McNiff (2013) recommend the planning phase, which is when the researcher and research participants met to establish the ground rules for the research. Accordingly, in February 2013, a survey adapted from Gonçalves, Gonçalves and Tavares (2011) was carried out, with responses from 17 members of the Anápolis-Brazil Municipal Health Council (a total of 24 full members), including 9 representatives of the accountability commission. The information obtained from structured and systematic observation was validated internally at this stage (Minayo, 2009). The survey sought to establish: (i) the level of the council members' knowledge of accountability reports; (ii) the functioning of the SUS and local needs in relation to decision-making processes; (iii) the level of their understanding of the quality of the information and the timeliness of its provision; and (iv) the need to train council members to analyze the reports. Cronbach's alpha (0.784) and the Spearman-Brown index (0.925) were used to measure the internal reliability of the findings generated by this instrument; both were found to be adequate for analytical purposes.

The action research was supported by the diagnosis and strategies defined in the planning phase. A focus group seminar was held at this stage for council members sitting on the accountability commission, as recommended by Minayo (2009, p. 87), since use of this technique and of data triangulation makes it possible to obtain valid qualitative indicators.

The assessment method proposed for analyzing accountability reports was reviewed in the final research phase, when meetings and the actions adopted after the seminar were observed (April to June 2013). This was followed by approval of the handbook dealing with the interpretation and analysis of accountability reports and training for council members in the 2014-2015 period. Further resolutions involving the accountability reports that had been issued after the participatory intervention (February and March 2016) were also analyzed. This follow-up verified the specific action taken by health council members, based on their use of the accountability reports analysis tool and on the opinions expressed by council members that were supported by Municipal Health Council resolutions. According to Ollaik and Ziller (2012), these stages provide external validation of the findings, determine whether they are replicable and reliable, and identify their direct impact or effect on the agent being analyzed.

All the research considerations applied in the methodological procedure we adopted were restricted to the Anápolis-Brazil Municipal Health Council. In fact, the interventionist nature of action research generates a direct relationship between the subject and object of the research, thereby restricting the findings to the reality that was assessed in the context of the Municipal Health Council in question. The study did not assess the readability of the reports after the template established by Municipal Health Council /Anápolis Resolution 038/2015 was introduced. 


\section{FINDINGS AND DISCUSSION}

The findings are structured in accordance with the following research stages: diagnosis and analysis of council members' perceptions of the accountability reports; assessment of the quality of the information supplied by the Accountability Reports; training for council members in how to read and analyze accountability reports; and findings of the post-intervention observation/assessment phase.

Observation of accountability meetings at the diagnosis stage showed that: a) the Accountability Report for the fourth quarter of 2011 was presented in approximately 25 minutes by means of a technical presentation; b) while the report was being presented the council members, in general, appeared to show little interest in what was being reported; c) council members spoke only occasionally and always on matters closely connected with their professional activities, with no discussion of any of the issues in the accountability report, or with regard to achieving the targets established in the Health Plan or the allocation of resources; d) the person presenting the report displayed impatience with regard to the matters raised by council members and said that the Municipal Health Council should address such issues officially by way of letters addressed to the health secretary or the mayor.

This observation exercise was evidence of the information gap that existed, with council members paying scant attention to the information provided in the Accountability Report, while the technical officer appointed by the local government limited himself to dealing with the technical-financial content of the presentation.

The critical theory of Habermas and his colleagues at the Frankfurt School, which is based on Hegel and Marx, criticizes the established social order that uses the esotericism of technical language to impose a system of domination on the weakest and least literate. Habermas argues that organizations cannot be understood without studying the existing power structure and forms of control. Therefore the tension reported here seems to correspond to the rupture that exists between the representatives of political power and those who represent the citizens. This organizational structure, which is created with the objective of restoring negotiation and compromise, results in a divergence of interests.

At this point it is important to mention the work of Hopper et al. (1987) that emphasizes the role of accounting when fighting over the distribution of power and controlling it. From this perspective, the intention of those in political power seems to be the integration of those members who represent citizens in order to control their capacity to claim compliance with health policy actions and to increase their commitment to political objectives, as if they are all enjoying public goods on an equal footing. While this power structure appears to be in control ideologically, the role and actions of council members are referred to as being a mere formality. In the view of Bobbio (1999), this type of social control leads to delegation and a reduction in citizen participation, which results in the consolidation of the interests of certain groups. Stralen et al. (2006) and Ceneviva and Farah (2012) state that new patterns of interaction and communication are needed between the bases of social control and participatory management, as those that currently exist are fragile.

In addition to the scenario we observed, document analysis revealed the existence of differences between the Municipal Health Council and local government, inasmuch as the Council did not approve the management reports for 2009, 2010 and 2011 because there were either disagreements with regard to the information provided, or a failure to provide the information requested.

In order to support research planning, in parallel with the application of the questionnaires, we analyzed the quality of the information in the accountability reports for 2010, 2011 and 2012, considering the dimensions of materiality, relevance and reliability, as demonstrated in Table 2.

Observations showed that the information disclosed in the accountability reports tends to be "restricted"; in other words, the information is characterized by a lack of detail, without any explanatory notes to justify budget allocations or re-allocations. There is none of the necessary correspondence between the targets and goals established in the multiannual plan or the Municipal Health Plan and budget resources. It is, therefore, difficult for external users to analyze reports with these characteristics. They naturally find themselves at a disadvantage in the deliberative process because they lack access to more detailed information, and because of the gap in their technical expertise when compared to that of the executive authorities (Abers et al. 2009). 
Table 2. Findings of the assessment of the accountability reports for 2010, 2011 and 2012

\begin{tabular}{|c|c|c|c|c|}
\hline \multirow{2}{*}{ Indicator } & \multirow{2}{*}{ Variable } & \multicolumn{3}{|c|}{ Dimension: Materiality } \\
\hline & & 2010 & 2011 & 2012 \\
\hline Quantitative data & $\begin{array}{l}\text { Evidence of the allocation of } \\
\text { financial resources }\end{array}$ & Medium & Medium & Medium \\
\hline $\begin{array}{l}\text { Degree of itemization of quantitative } \\
\text { data }\end{array}$ & $\begin{array}{l}\text { Specification of the source of } \\
\text { financial resources }\end{array}$ & Low & Low & Low \\
\hline $\begin{array}{l}\text { Relationship between MHO and } \\
\text { MHC }\end{array}$ & $\begin{array}{l}\text { Council participation in } \mathrm{MHO} \\
\text { decisions }\end{array}$ & Restricted & Restricted & Restricted \\
\hline $\begin{array}{l}\text { Authority's relevant plans and } \\
\text { expectations }\end{array}$ & $\begin{array}{l}\text { Goals and targets for following } \\
\text { year }\end{array}$ & Low & Low & Low \\
\hline Indicator & Variable & \multicolumn{3}{|c|}{ Dimension: Relevance } \\
\hline Predictive value & $\begin{array}{l}\text { Financial resources provided for in } \\
\text { proposal/budget law }\end{array}$ & Restricted & Restricted & Restricted \\
\hline Confirmatory value & $\begin{array}{l}\text { Comparison of results achieved } \\
\text { with targets set for the health area }\end{array}$ & Medium & Medium & Medium \\
\hline & Reporting frequency & Restricted & Restricted & Restricted \\
\hline Timeliness & $\begin{array}{l}\text { Availability of the report in } \\
\text { question }\end{array}$ & Restricted & Restricted & Restricted \\
\hline Indicator & Variable & \multicolumn{3}{|c|}{ Dimension: Reliability } \\
\hline Accuracy & Evidence of legal content & Restricted & Restricted & Restricted \\
\hline Describable and measurable value & $\begin{array}{l}\text { Forecast of resources for financial } \\
\text { years in PPAs [multiannual plans] } \\
\text { for the health area }\end{array}$ & Low & Low & Low \\
\hline Prudence & $\begin{array}{l}\text { Financial resources reserve for } \\
\text { contingencies }\end{array}$ & Restricted & Restricted & Restricted \\
\hline & Budget rectifications & Restricted & Restricted & Restricted \\
\hline Contents & $\begin{array}{l}\text { Disclosure of priorities for the } \\
\text { allocation of financial resources }\end{array}$ & Medium & Medium & Medium \\
\hline Neutrality & $\begin{array}{l}\text { Disclosure of points requiring } \\
\text { improvement }\end{array}$ & Restricted & Restricted & Restricted \\
\hline
\end{tabular}

Source: prepared by the authors.

Training was provided to health council members during the research action phase by way of a seminar. This was done to improve their skills in interpreting and analyzing accountability reports. Prior to the training, a focus group was held with members of the Municipal Health Council's. This focus group addressed: (i) the importance of an assessment of health accountability reports by the Municipal Health Council; (ii) the role of council members in this assessment; (iii) the relationship between the health plans set out in the multiannual plan, the Budgetary Guidelines Law and the annual Budget Law, and the health accountability reports; (iv) the establishment of priorities with regard to how the allocation of resources was recorded in the accountability reports; (v) a comparison between the targets set and those attained in healthcare; and (vi) the perception of the suggestions made by the Municipal Health Council to local government.

In general, the focus group indicated that council members regard the Municipal Health Council's assessment of accountability reports to be important. Although council members have made efforts to carry out the stages of the accountability process as proposed by Gomes (2015) (analysis of the management results, assessment of how the funds are used, identification of the people responsible for rejecting the accounts and the sanctions imposed), they acknowledge the difficulty of doing so on the basis of the accountability reports because of the technical nature of the terms used, as we identified in the council members' own words: 


\begin{abstract}
"What we do on the council is something else, $[\ldots]$ where we're highly focused on one thing and let other things pass without comment, but we lack technical expertise and we're in no position to assess everything process by process. We have difficulty in analyzing the more technical information and we don't have accounting advisers to help us as we requested at several council meetings some years ago. (Council member 2). It's very difficult for us, because everything comes in account items, figures, you don't know how it was done, all very technical. I think that accountability reporting should be simpler [...] to understand all this you need audit work". (Council member 3). [emphasis added]
\end{abstract}

Training was subsequently provided for accountability commitee members of the Municipal Health Council, when the importance of planning instruments for assessing accountability reports was explained. The AR for the first four months of 2012 was used as an example, with council members being offered guidance concerning the indicators and variables using the tool proposed by De Oliveira Gonçalves et al. (2010). The training course encouraged council members to put forward their own considerations and offer their perceptions concerning the accountability reporting analysis tool that should be included in the opinion that sets out the council's conclusions following its analysis of the 2012 AMR. This stage validated the information that was assessed in the report based on an analysis conducted jointly with council members. At the end of the course, the council members' views on the topic were obtained:

"The explanations provided here give me the impression that we are approving something that has nothing to do with it [...] we don't have the criteria" (Council member 4). [emphasis added]

With regard to resource allocation priorities, attention is drawn to the following statements by council members:

"I think they're priorities for someone who's not an expert; they have no basis on which to say no. Accountability reports are about what was spent, so in this case [of the accountability reports] I don't see how to establish priorities" (Council member 3).

"It's not there and it's not explained in the reports". (Council member 2) [emphasis added]

Their statements show that the support of the Health Conference report, the Municipal Health Plan and the Annual Health Programs for the Multiannual Plan are not reconciled with the information presented in the accountability reports. As Vieira (2009) mentioned, when a situation occurs then actions take place through inertia, with no proper comparison being made between what was planned and what was actually done. It should be mentioned here that, as O'Donnell (1998) states, in these types of accounts the Municipal Health Council is unable to deal with specific issues such as this on its own, because it depends on a network of agencies that include the controlling bodies that are committed to providing support for these actions.

In the light of the findings, the following were presented at the Municipal Health Conference in 2013: (i) a proposal for a draft Council resolution for standardizing/creating templates for four-monthly and annual accountability reports; and (ii) the creation of a handbook providing council members with guidance on interpreting and analyzing reports, with particular regard to the allocation of resources.

At the assessment stage after the research intervention, observations were made of the results achieved by the training provided to health council members and from changes in the report analysis process, when it was found that several Municipal Health Council actions had been influenced by the perceptions acquired by council members at the training seminar.

Output from this seminar included a template that was designed for Municipal Health Council resolutions, and that dealt with overseeing health management by way of regular, four-monthly reports and Anápolis Management Reports. This template uses criteria established in advance for use by the local government in drafting the accountability report so as to permit the systematic, substantiated and impartial analysis of the way in which SUS resources are being allocated on an equal footing. In relation to this, Duarte and Machado (2012, p.137) write that "a wise and committed manager will be diligent in finding ways to strengthen the health council, so as to work with it as a partner, and not to cover up his or her failings, but rather to legitimize and consolidate his or her management. The aim is cooperation and not co-option".

Following extensive discussion of a draft resolution, the Municipal Health Council passed Anápolis Municipal Health Council Resolution 038/2015, which dealt with overseeing health management and approving the SUS Accountability Reports Analysis Handbook for use by the municipality. Progress was thus made in the organization of civil society that resulted in concrete action through action research. 
Unstructured interviews were then conducted with the Municipal Health Council chairperson and Accountability Commitee members of the Municipal Health Council. The opinions were expressed after the research intervention (in November 2015).

The researchers were provided with Anápolis Municipal Health Council Resolutions 027/2015 (Anápolis Management Report 2010), 028/2015 (Anápolis Management Report 2011), 028/2015 (Anápolis Management Report 2012), 059/2015 (Anápolis Management Report 2013), 060/2015 (Anápolis Management Report 2014) and 084/2016 (Anápolis Management Report 2015 - approved with reservations), which approved the Anápolis Management Reports for the years in question. Although annual reports were not drawn up on the basis of Anápolis Municipal Health Council Resolution 038/2015 of 03/31/2015, council members analyzed Anápolis Management Report 2014 using the parameters established in it, according to the following extract taken from Anápolis Municipal Health Council Resolution 060/2015.

Attached is the Consolidated Report on the results of the budget and financial performance in the health area, indicating the value and source of the resources allocated in the period; the health services provided, specified by government program and initiative; and the value of the financial resources reserved for contingencies (contingency reserve) (Anápolis Municipal Health Council Resolution 060/2015, of August 18, 2015).

The 2015 Anápolis Management Report was analyzed in line with Anápolis Municipal Health Council Resolution 038/2015, and was approved with reservations. From analysis of council members' reservations, it is clear that analysis of the report improved, as it presented a detailed check of those items (variables) that have to be provided.

Another action we identified consisted of questions that were asked of the SUS to complement the information not included in the Anápolis Management Reports for 2010, 2011, 2012, 2013, 2014 and 2015. An example of this is the opinion expressed with regard to Anápolis Management Report 2015, by means of Resolution Ad Referendum 084/2016, which approved the report with reservations and requested clarification from the SUS concerning the lack of information. It also asked for a review and/or rectification of the data presented, and suggested that the targets that were not met should be prioritized in the health planning process.

In the light of these changes, the opinions resulting from analysis of the Anápolis Management Reports for 2010 to 2015 now make use of parameters when assessing the information, and this has facilitated the relationship between council members and local government. Authors who discuss progress in the democratic process (O'Donnell, 1998; Bobbio, 1999; Abers et al. 2009; Gomes, 2015) on the basis of the accountability process have written of a shift in accountability in public management, which was previously the sole domain of government. Accountability now involves local activists and without determined and persistent action on the part of the latter, there is no efficient social control over government.

In the light of the critical theory of the Frankfurt School, the problem faced in this last phase of the process, when the group was trained in how to read and interpret accountability reports, is that it produces a feeling of false empowerment. This is a behavioral and socialization process according to the standard that is required by political power. This is not freedom and this apparent freedom is slavery and alienation, to the extent that the most unprotected citizens will remain in the same position in the power structure as they were before this training course (Vieira, 2017). They will become alienated, more obedient, more manageable and instrumentalized, and they will more easily assume the objectives of political power as their own, thereby losing the notion of their own interests and assuming the interests of others as if they were their own. Power, knowledge, and discipline are associated concepts in this line of thinking, in which the processes of socialization become instruments of exploitation.

\section{FINAL CONSIDERATIONS}

When council members effectively exercise their responsibilities this is not described as society "overseeing" public authorities, but is rather part of society's active participation in endeavors in the field of health as it constantly seeks to improve the application of resources from the standpoint of Habermas's (1989) public sphere theory.

The public sphere is central to the good governance of any country. Without a democratic and properly functioning public sphere the public administration authority's senior officers are hardly accountable to or for anyone, and citizens will effectively have no influence over political decisions. Ideal public governance, therefore, is normative. It is an ideal of good accountable governance, which requires flows of information, freedom of speech and active participation, all of which are the best guard against the abuse of power (Splichal, 1999). 
More important than the results achieved by this research was the search for a path to the conscious empowerment of citizens to take decisions on matters of common interest. The public sphere is where free and equally-empowered citizens meet to share information, debate, discuss and deliberate (Odugbemi, 2008). From this standpoint, transparency in the allocation of resources is the very foundation of accountability and an important pillar of democracy and of stronger social control, in the search for information that is relevant and comprehensible. Finally, Fox (2018) emphasizes that the concept of social control has historically been linked to processes of democratization in South America. It highlights the idea that public sector supervision must be in the hands of citizens.

The contribution of this study is that it used action research to enable social control to overcome difficulties relating to the accountability reporting process, especially in the environment we observed, in which there was a lack of comprehensible information and of variables that would enable the manager to know what parameters should be used in drawing up the accountability report. The problem here discussed raises the question as to what extent management instruments that call for the convergence of solutions can be transformed into instruments of manipulation or alienation? To what extent do they serve as a cushion so that the structure of power remains untouched? In a democratic society, the accountability of politicians should allow everyone to be on an equal footing in terms of their access to the exercise of their rights, freedoms and guarantees, and ensures the fight against the perpetuation of the dominant power structures that cross generations.

The contribution of this work was that it shed some light on a part of social reality that is usually hidden in the shadows, and brought to the debate other perspectives for evaluating the instruments of management or the concertation of interests; a concertation of interests that according to functionalism would lead to effectiveness. This ideologically assumes that everyone would be metaphorically in the same boat. This work questions, however, whether they will all be in the same sea, and while some may be sailing, others may have to swim. It certainly seems that it is possible to achieve effective citizen participation in establishing a public health policy and monitoring public funds using the same management instruments, but with different interpretations: for some this will happen by negotiation, which is how society is transformed incrementally, while for others progress will only result from radical action.

As a suggestion for future researchers, an analysis might be made of the readability of accountability reports following publication of Anápolis Municipal Health Council Resolution 038/2015.

\section{REFERÊNCIAS}

Abers, R. N., Formiga-Yohnsson, R., Frank, B., Keck, M. E., \& Lemos, M. C. (2009). Inclusion, deliberation and control: The three dimensions of democracy in committees and consortia of brazilian river basins. Ambiente \& Sociedade, 12(1) DOI: https://doi.org/10.1590/S1414-753X2009000100009.

Alvarez, M. C. (2004). Controle social: notas em torno de uma noção polêmica. São Paulo Perspec., 18(1), 168176. DOI: https://doi.org/10.1590/S0102-88392004000100020.

Anápolis (GO). Municipal Health Council. Resolução CMS/ANÁPOLIS N 038/2015. Provides for Health Management Supervision through the Quarterly Reports and the Annual Management Reports (RAG). Anápolis-GO. Official Gazette Anápolis Municipality, April 23, 2015.

Municipal Health Council. Resolução Ad Referendum CMS/ANÁPOLIS No 084/2016. Approves the 2015 Annual Management Report-RAG and makes further arrangements. Anápolis-GO, September 9, 2016.

Municipal Health Council. Resolução CMS/ANÁPOLIS $N^{o}$ 027-02/2015. Approves the Annual Management Report-RAG 2010. Anápolis-GO, January 27, 2015.

Municipal Health Council. Resolução CMS/ANÁPOLIS $N^{o}$ 028-02/2015. Approves the Annual Management Report-RAG 2011. Anápolis-GO, January 27, 2015.

Municipal Health Council. Resolução CMS/ANÁPOLIS No59/2015. Approves the Annual Management Report-RAG 2013. Anápolis-GO, August 18, 2015.

. Municipal Health Council. Resolução CMS/ANÁPOLIS N ${ }^{\circ} 060 / 2015$. Approves the Annual Management Report-RAG 2013. Anápolis-GO, August 18, 2015.

Bicalho, M. dos S. (2008). Health counsellors building the social control of SUS. Psicologia em revista, 10 (14), 149-154.

Bilhim, J. (2013) Teoria Organizacional: estruturas e pessoas. Lisboa: ISCSP. 
Bobbio, N. (1999). Democracia. In N. Bobbio, \& N. Matteucci, \& G. Pasquino, (Orgs.). Dicionário de Política. 12. ed. Brasília: Editora da Universidade de Brasília.

Boudon, R.; Bourricaud, F. (1993). Dicionário Crítico de Sociologia. São Paulo: Ática, 653p.

Ceneviva, R., \& Farah, M. F. S. (2012). Evaluation, information and responsiveness in public sector. Rev. Adm. Pública, 46(4), 993-1016. DOI: https://doi.org/10.1590/S0034-76122012000400005.

Cooper, D J. (1983). Tidiness, muddle and things: commonalities and divergencies $\mathrm{n}$ two approaches to management accounting research. Accounting, Organizations and Society, 8, 2/3, 269-86.

Correia, M. V. C. (2006). Controle social na saúde. Serviço Social e Saúde: formação e trabalho profissional. São Paulo: OPAS, 111-138.

De Oliveira Gonçalves, A., de Souza Gonçalves, R., Lustosa, P. R. B., \& Celestino, E. C. (2010). From the Health Secretary to the Council: analysis of the accountancy reports based on the qualitative characteristics of accounting information. Revista de Contabilidade e Organizações, 4(8), 92-111. DOI: https://doi. org/10.11606/rco.v4i8.34760.

Dias, J. C. R., \& Vasconcelos, M. T. C. (2015). As Características Qualitativas da Informação Contábil no Desenvolvimento do Controle Social: uma Análise da Percepção dos Conselheiros Municipais do Recife sobre a Utilidade das Informações Contábeis. Contabilidade Vista \& Revista, 26(2), 14-40.

Durkheim, É. (1951). Suicide: A Study of Sociology. Translated by John S. Spaulding and George Simpson. Edited with an Introduction by George Simpson.

Duarte, E. B., \& Machado, M. D. F. A. S. (2012). The exercise of community participation in the sphere of Canindé's Municipal Council of Health. Saúde e Sociedade, 21(suppl. 1), 126-137. DOI: https://doi.org/10.1590/S010412902012000500011.

Fox, J. A. (2018). The Political Constrution of Accountability Keywords. IDS Bulletin, 49(2). DOI: https://doi. org/10.19088/1968-2018.136.

Gomes, E. G. M. (2015). Management councils of public policies: theoretical aspects on the potential of a democratic and effective social control. Cadernos EBAPE. BR, 13(4), 894. DOI: https://doi.org/10.1590/1679395123196.

Gonçalves, A.O., Gonçalves, R. de S., \& Tavares, A. L. (2011). The health advisors' view regarding the accounting reports of the city of Natal (Rio Grande do Norte), Brazil. Saúde e Sociedade, 20(3), 659-672. DOI: https:// doi.org/10.1590/S0104-12902011000300012.

Grisotti, M., Patrício, Z. M., \& Silva, A. D. (2010). The participation of users, workers and counselors of health: a qualitative study. Ciência \& saúde coletiva, 15(3), 831-840. DOI: https://doi.org/10.1590/S141381232010000300026

Habermas, J. (1989). 1962. The Structural Transformation of the Public Sphere, 28. Cambridge, MA: MIT Press.

Hobbes, T. (2019). Leviatã: matéria, forma e poder de um estado eclesiástico e civil. LeBooks Editora.

Hopper, T.; Powel, A. (1985). Making sense of research into organizational and social aspects of management accounting: a review of its underlying assumptions. Journal of Management Studies, 22 (5), p. 429-465.

Hopper, T; Storey, J.; Willmott, H. (1987). Accounting for Accounting: Towards the Development of a dialectical view, Accounting, Organizations and Society, 12 (5), p. 437-456.

Janowitz, M. (1975). Sociological theory and social control. American Journal of sociology, 81(1), 82-108. DOI: https://doi.org/10.1086/226035.

Lewin, K. (1946). Action research and minority problems. Journal of Social Issues, 2(4), 34-46. DOI: https://doi. org/10.1111/j.1540-4560.1946.tb02295.x.

Lourenço, R.; Sauerbronn, F. (2016). Revistando possibilidades epistemológicas em contabilidade gerencial: em busca de contribuições de abordagens interpretativas e críticas no Brasil. Revista Contemporânea de Contabilidade, 13 (28), p. 99-122.

Lubenow, J. A. (2007). A categoria de esfera pública em Jürgen Habermas: para uma reconstrução da autocrítica. Cadernos de Ética e Filosofia Política, 10 (1), p.103-123. 
Martins, P. C., Cotta, R. M. M., Mendes, F. F., Francheschinni, S. D. C. C., Priore, S. E., Dias, G., \& SiqueiraBatista, R. (2008). C. Health councils and social participation in Brazil: shades of an utopia. Physis (Rio J.), $18(1), 105-121$.

McNiff, J. (2013). Action research: Principles and practice. Routledge.

Medeiros, A. K. de, Crantschaninov, T. I., \& da Silva, F. C. (2013). Studies on accountability in Brazil: metaanalysis of Brazilians periodicals of areas of administration, public administration, political science and social science. Rev. Adm. Pública, 47(3), 745-775. DOI: https://doi.org/10.1590/S0034-76122013000300010.

Mészáros, I. (1997). A necessidade do controle social. São Paulo: Ensaio Editora.

Miguel, L. F. (2005). Accountability impasses: dilemmas and alternatives of political representation. Revista de Sociologia e Política, 25, 25-38. DOI: https://doi.org/10.1590/S0104-44782005000200004.

Miller, Peter; O'Leary, Ted (1987) Accounting and the construction of the governable person, Accounting, Organizations and Society, 12 (3), 235-265.

Minayo, M. C. S. (2009). The construction of qualitative indicators for the evaluation of changes. Revista Brasileira de Educação Médica, 33(1 Supl 1), 83-91. DOI: https://doi.org/10.1590/S0100-55022009000500009.

O 'Donnell, G. (1998). Horizontal accountability and new poliarchies. Lua Nova: Revista de Cultura e Política, (44), 27-54. DOI: https://doi.org/10.1590/S0102-64451998000200003.

Odugbemi, A. (2008). Public opinion, the public sphere, and quality of governance: An exploration. In S. Odugbemi \& T. Jacobson (Eds.), Governance reform under real-world conditions. Citizens, stakeholders, and voice (pp. 15-37). Washington, D.C.: The World Bank.

Ollaik, L. G., \& Ziller, H. M. (2012). Conceptions of validity in qualitative studies. Educação e Pesquisa, 38(1), 229-241. DOI: https://doi.org/10.1590/S1517-97022012005000002.

Pinho, J. A. G. de, Sacramento, A. R. S. (2009). Accountability: can we now translate it into Portuguese? Rev. Adm. Pública, 43(6), 1343-1368. DOI: https://doi.org/10.1590/S0034-76122009000600006.

Roberts and Scapens (1983) describe accounting as the language of capitalism. Roberts J. and Scapens, R. (1983). Accounting in divisionalized companies: some initial reflections, paper to the Management Control Workshop Conference, Manchester Business School, December.

Ross, E. A. (1901). Social Control: A Survey of the Foundations of Order. New York: Macmillan.

Ross. E. A. (1936). Seventy Years of It-an Autobiography. New York: Appleton-Century.

Ryan, Bob; Scapens, Robert W.; Theobold, Michael. (2002). Research Method and Methodology in Finance and Accounting. London: Wouth Wester: Cengage Learning.

Saliba, N. A., Moimaz, S. A. S., Ferreira, N. F., \& Custódio, L. B. D. M. (2009). Healthcare Councils: knowledge about health care. Rev. Adm. Pública, 43(6), 1369-1378. DOI: https://doi.org/10.1590/S003476122009000600007.

Soares, M., Paton, C., dos Santos, A. F., \& Bezerra, F. A. (2009). Soares, M., Paton, C., dos Santos, A. F., \& Bezerra, F. A. (2009). A Discussion on the Feasibility of Research-action in Accounting. Revista de Contabilidade e Organizações, 3(7), 109-126. DOI: https://doi.org/10.11606/rco.v3i7.34753.

Splichal, S. (1999). Public opinion. Developments and controversies in the twentieth century. Lanham, MD: Rowman \& Littlefield.

Stralen, C. J. V., Lima, A. M. D. de, Sobrinho, D. F., Saraiva, L. D. E. S., Stralen, T. B. D. S. V., \& Belisário, S. A. (2006). Health Councils: effectiveness of social control in municipalities of Goiás and Mato Grosso do Sul. Ciência \& saúde coletiva, 11(3), 621-632. DOI: https://doi.org/10.1590/S1413-81232006000300011.

Teixeira, Juliana Cristina, Nascimento, Marco César Ribeiro, \& Carrieri, Alexandre de Pádua. (2012). Triangulation method in administration studies: generating conversations between paradigms or mere "convergent" validations? Revista de Administração Pública, 46(1), 191-220. DOI: https://doi.org/10.1590/S003476122012000100010 .

Thiollent, M. (1997). Pesquisa-Ação nas Organizações. 1. ed., São Paulo: Editora Atlas. 
Vieira, F. S. (2009). Advances and challenges of the Unified Health System planning. Ciência \& saúde coletiva, 14 (Supl 1), 1565-1577. DOI: https://doi.org/10.1590/S1413-81232009000800030.

Vieira, R. (2017) Paradigmas Teóricos da Pesquisa em Contabilidade. In Major e Vieira (2017). Contabilidade e Controle de Gestão: Teoria, Metodologia e Prática. Lisboa: Escolar Editora.

\section{How to cite this paper}

Gonçalves, A. de O.; Bilhim, J. de A. F.; Rezende, R. B. de; \& Gonçalves, R. de S. (2021). Accountability and social control: how the process works. Revista de Contabilidade e Organizações, 15:e166382. DOI: http://dx.doi.org/10.11606/issn.1982-6486.rco.2021.166382 